\title{
Thinking about Creativity in Science Education
}

\author{
Yannis Hadzigeorgiou ${ }^{1}$, Persa Fokialis ${ }^{1}$, Mary Kabouropoulou ${ }^{2}$ \\ ${ }^{1}$ Department of Pre-School Education and Educational Design, University of the Aegean, Rhodes, Greece \\ ${ }^{2}$ Department of Primary Education, University of the Aegean, Rhodes, Greece \\ Email: hadzigeo@rhodes.aegean.gr
}

Received June $28^{\text {th }}$, 2012; revised July $26^{\text {th }}$, 2012; accepted August $12^{\text {th }}, 2012$

\begin{abstract}
In this paper we discuss the notion of creativity in the contexts of science and science education. In doing so, we consider and reflect on some taken-for-granted ideas associated with school science creativity, such as inquiry science, and integrating art and science, while we search for a notion of scientific creativity that is compatible with both the nature of science and the general notion of creativity, and also realistic in the context of school science education. We then propose a number of activities/strategies that encourage creativity, and more specifically imaginative/creative thinking, through the learning of school science.
\end{abstract}

Keywords: Creativity; Imagination; Science; Science Education

\section{Introduction}

Is there anything new to be said about creativity when the literature on the subject is literally voluminous and covers almost half a century's research? An ERIC search revealed that well over one million articles have been written about creativity in the contexts of education and learning, and a little over one hundred and fifty thousands about creativity in the context of, or relating to, science education. Yet the above question is quite timely, now that creativity is increasingly considered a crucial ability for the future. As we are entering a new era, creativity is not just becoming increasingly important (Pink, 2005), but it seems that "our future is now closely tied to human creativity" (Csikszentmihalyi, 1996: p. 6). Gardner (2010), in his Five Minds for the Future, has argued for the crucial role of creativity, as a one of the five cognitive abilities that leaders of the future should seek to cultivate.

The fact that curriculum documents worldwide make explicit reference to creative thinking as a worthwhile aim of education reflects the great importance we attach to creativity. If the world, as we know it today, is the result or the product of the creative thinking of few individuals, and if progress in any human endeavor and field of study is due exclusively to the development of new ideas and new ways of seeing reality, then it makes sense to make creative thinking a curricular goal. Science is one of the disciplines that can make a contribution to the achievement of this goal. The current Creative Little Scientists project, aiming to foster creativity in early childhood in several European countries, is evidence of the priority given to creativity in general and creativity through science in particular, especially in early years education (www.creative-little-scientists.eu).

However, there is empirical evidence that students do not appreciate the creative thinking required in doing science, and that they do not view science in general as a creative endeavour (see Schmidt, 2011). This is somehow paradoxical, given that creativity is inextricably tied to the nature of science itself (McComas, 1998), and also the consensus among scientists and science educators that scientific knowledge is indeed the product of creative thinking (Osborne et al., 2003). On the other hand, the rhetoric around creativity in general and scientific creativity in particular is also something that needs to be considered. Slogans such as "creative science", "creative problem solving” and "creative inquiry" may remain just slogans if we keep on paying lip service to these notions (Kind \& Kind, 2007; Schmidt, 2011) and if we tend to identify creativity simply, or mainly, with the generation of novel ideas without appreciating the special role of imagination (Holton, 1996) and the role of content knowledge in creative thinking (Rowlands, 2011).

It is the purpose of this paper to discuss the notion of creativity in the contexts of science and science education and then propose a number of activities/strategies that encourage creativity, and more specifically imaginative/creative thinking, through the learning of school science. What Jean Piaget has said about creativity provides a purpose for the writing of this paper, since slogans around creativity abound, and since one has to critically look at what scientific creativity is, before implications for science education are drawn and certainly before activities that supposedly make children more creative are designed and implemented.

The principal goal of education is to create men who are capable of doing things, not simply of repeating what other generations have done-men who are creative, inventive, and discoverers. The second goal of education is to form minds which can be critical, can verify, and not accept everything they are offered. The great danger today is of slogans, collective opinions, ready-made trends of thoughts. We have to be able to resist individually, to criticize, to distinguish between what is proven and what is not. (Ginsberg \& Opper, 1969: p. 5)

\section{Creativity in Science}

The idea that science is a creative endeavour is indisputable. Scientific ideas are creations of the mind. As Einstein and Infeld (1938) put it, "Physical concepts are free creations of the human mind, and are not, however it may seem, uniquely determined by the external world.” (p. 33). The invention, of course, of concepts and theories, more often than not, requires extraordinary imaginative leaps, but it is also true that even everyday scientific work, like, for example, problem finding and solving, hypothesis formation, and modelling, requires imagi- 
native/creative thinking, although the latter is not usually associated with novelty.

If creativity is one's "ability to come up with new ideas that are surprising yet intelligible, and also valuable in some way" (Boden, 2001: p. 95), then novelty and value should be the two conditions or characteristics of scientific creativity too. And according to these two characteristics, scientific creativity can be identified either with "historical creativity" (i.e., when something, like a new idea, a new theory, a new discovery, is historically new) and/or with "personal creativity" (when something is new in a personal sense regardless of whether that something is not new to others) Boden, 2004, for a distinction between h-creativity and p-creativity). It can also be identified with both extraordinary, "big C creativity" (BCC) and ordinary, everyday, "little c-creativity” (LCC) (Craft, 2001). It seems reasonable to identify LCC with "normal science" and BCC with "revolutionary science”, according to Kuhn's (1970) terminology, since LCC is akin to imaginative and what Craft (2001) calls "possibility thinking", which is a kind of thinking that takes place in everyday life.

In distinguishing between ordinary (LCC) and extraordinary creativity (BCC) one may be tempted to think of the latter as a purely personal ability, since it involves imaginative leaps and, sometimes, sudden insights. But since it (BCC) exists within a socio-cultural system, consisting of three interacting elements (i.e., a domain or culture that sets symbolic rules, a person who brings new ideas into the domain, and a community of experts who will validate the produced novelty) (Feldman, Czikszentmihalyi, \& Gardner, 1994), the purely personal dimension of creativity, even in the case of some rare individuals, who make new discoveries and invent new scientific theories, seems to be complemented with a social dimension. It is for this reason that creativity is increasingly considered a socio-related issue (Miell \& Littleton, 2004; Ricchuito, 1996). Whitehead's (1957: p. 116) view that "Everything of importance has been said before by somebody who did no discovered it", certainly reflects the sociological view that the source of ideas is the individual and would be "more correct to say that s/he participates in think further what others have thought before her/him" (Mannheim, 1972: p. 3). However, it raises an issue in regard to the originality of the ideas put forward by scientists.

To pursue this issue further is beyond the scope of this paper, but it is nonetheless important to consider it when approaching creativity in the context of school science (see next section). Suffices to say here, it makes sense to view creativity as a mental ability emerging from a social context, which is, anyway, compatible with the social dimension of science itself. In actual fact, the view that science is a social activity- "constitutively social”-as Woolgar (1988: p. 13) put it-says much than science having a social dimension. It rather conveys the view that that the very nature of science is social. There is evidence that creativity emerges from interacting scientists (Latour \& Woolgar, 1986). The image of the "lone star" scientist, working in the lab and experiencing a sudden inspirations and insight, thus solving a problem on his/her own, although not completely a myth, is very rare, at least nowadays. Interactions among scientists and among groups of scientists play a catalytic role in the creation of knowledge (Feldman, Czikszentmihalyi, \& Gardner, 1994; Simonton, 2004).

However, in talking about scientific creativity, the personal dimension of creativity, which is associated with the aesthetic element of science, needs to be considered. In actual fact, the philosopher and historian Thomas Kuhn has stressed its importance in scientific revolutions: "Aesthetic considerations can be decisive. Though they often attract only a few scientists to a new theory, it is upon those few that its ultimate triumph may depend." (Kuhn, 1970: p. 156). The history of science provides evidence that aesthetic factors did play a major role in theory construction and in influencing scientific practice in general (Hadzigeorgiou, 2005). It should be noted that the common ground shared by art and science has been recognized after a shift from positivist epistemology took place. Science, in fact, might have a greater commonality with art than was originally thought in a more positivist era (Tauber, 1996).

The idea that "wholeness", through its association with beauty, can be experienced during one's appreciation of both a scientific theory and a work of art, is evidence of the common ground shared by science and art (Bohm, 1998). This means that scientific truth is not judged solely on the grounds that scientific ideas correspond to certain observable facts, but also because they contribute to a sense of wholeness (Bohm, 1988). That aesthetic factors contribute to this sense of wholeness is well documented in the literature (Root-Bernstein, 2002; McAllister, 1996, 1997).

What is important to point out is that inspiration and imaginative engagement are shared by both artists and scientists. And that at the moment of creation, the boundaries between art and science cease to exist and aesthetics play a central role (Miller, 2001). What is also important to bear in mind is that with the advent of quantum physics and the theory of relativity, the distinction between art and science became blurred. Not only aesthetics (Tauber, 1997; Root-Bernstein, 2002) but also symbolic language became central to the creation of scientific knowledge. Werner Heisenberg described Niels Bohr as an artist, who, in using his brushes and various colours, tried to convey, just like an artist, his own images to other scientists (Heisenberg, 1971). And Bohr himself did point out that in the new physics, where one studies the behaviour of atoms, "language can be used as in poetry” (Tolstory, 1990: p. 16). Miller's (2001) work on the life and work of Einstein and Picasso reveals parallels between the two men, and provides an insight into how the shift from positivism influenced both art and science. For the distinctions between the visible and the invisible, the distant and the near became blurred, and the unification of time and space, the idea of simultaneity and that no two observers see exactly the same thing, were ideas that were common in both art and science. The similarities between cubism and the theory of relativity is evidence, according to Miller's (2001) analysis, of those common ideas. Moreover, the creation of mental imagery and analogies, used by both artists and scientists, points to the crucial role of imagination in both artistic and scientific creativity.

Yet, despite these similarities, the differences between art and science should also be stressed. For example, while in art "something travels", in the sense that people, who did not participate in the creative act (which produced a piece of art), feel delight and inspiration, and are carried away, in science the delight and inspiration are closely tied to the act and context of the scientific discovery itself, that is, to the scientist who made the discovery or developed a scientific theory (Medawar, 1967: p. 172). Also in science there is always the process of verification, which does not exist in art.

Simonton (2004), in using as examples The Principia, The Republic, Hamlet, The Last Supper, and the Fifth Symphony, makes Newton's scientific creativity quite distinctive from all 
the rest, since, as his argument goes, any literate person can get an understanding of Plato's logical argument in the Republic, or an idea of the dramatic development in Hamlet and also what is graphically conveyed in the Last Supper or musically expressed in Beethoven's Fifth Symphony, but makes no sense of what Newton in The Principia actually put forward. It is perhaps this reason why scientific creativity is culturally valued more than artistic creativity.

From neuroscience’s perspective, Dietrich's (2004) work on creativity types is very informative, since it can help us differentiate between scientific and artistic creativity. He classifies creativity into four major types: deliberate and cognitive, deliberate and emotional, spontaneous and cognitive, and spontaneous and emotional. Scientific creativity requires sustained attention and focus on an idea or problem and is therefore the result of a deliberate cognitive function (taking place in the prefrontal cortex), although there are occasions when spontaneous cognitive creativity makes one solve a problem. Artistic creativity, on the other hand, is associated with spontaneous and emotional functioning (taking place in the amygdala). Scientific creativity, more often than not, is based on logic, in the sense that "Once a scientist masters the logic of science and the substance of a particular discipline, creativity is assured." (Simonton, 2004: p. $6)$. In other words, what is usually considered a mystical inspiration, a product of some extraordinary ingenuity, may very well be the product of logic. Although logic is one of the sources of scientific creativity-the other being genius, chance and zeitgeist, according to Simonton (2004) - it is nonetheless an important one. There is consensus that scientific creativity is always matched by rationality, with experiments playing a crucial role (Schwartz, Lederman, \& Crawford, 2004). Scientific ideas, as was pointed out previously, are always subject to verification through experimental testing.

The comparison that has been made between art and science is quite crucial, given the interdisciplinary connection between the two in the context of education. This issue I will take up in the next section, but here the point that should be made concerns both the similarities and differences between the two, which need to be considered when one approaches creativity. Art is more imaginary than science, in the sense that in science logic is always a complement to imagination. Which though is more creative is hard to answer, granted that both can be creative, and in fact transformative, in the sense that they can both contribute to our change of outlook on the world (Miller, 2001).

This comparison may lead one to identify scientific creativity mainly with two general abilities, that is, imaginative and logical thinking. Both intellectual abilities, in actual fact, are considered necessary, although not sufficient, for the generation or production of novel ideas. Yet creativity, as an emergent ability, is the result of a complex interplay of several factors, such as intellectual abilities (i.e., problem finding, seeing problems in novel ways), prior, domain-specific knowledge, personality traits (i.e., self-efficacy, risk taking, a tolerance for ambiguity), motivation and environment (Sternberg, 2006). This complexity, coupled with the way and the circumstances under which scientific ideas burst forth (Gardner, 1994, 1997), makes scientific creativity an unpredictable ability or event. For it is also true that the subconscious and unconscious have also played a catalytic role in the generation of novel ideas and problem solutions. According to the literature, dreaming and daydreaming have resulted in sudden and unexpected insights — even illuminations (Vernon, 1970; Kind \& Kind, 2007).
The age of those involved in the creation of novel and revolutionary scientific ideas is also a factor that needs some consideration with regard to scientific creativity, as is the fact that scientists, more often than not, are "deliberately creative" (in the sense that they deliberately look for novelty that can be useful to society). The fact that the scientists who transformed both their disciplines and the way people see the world were very young-i.e., in their early or mid-twenties (Simonton, 2004), is something that may very well have implications for science education.

It is therefore apparent that scientific creativity is the outcome of a complex interplay of factors that cannot be predicted. Yet despite the complexities inherent in science, as a field of inquiry, and despite the complexities in approaching it as a creative endeavor, a reliable picture of it should be based upon the following statements (Kind \& Kind, 2007: p. 14):

- Scientific theories are creative products (ideas) made by scientists.

- Many scientists work on the same problems and new ideas (theories, laws) emerge by common effort.

- Most science theories develop over a long period in small steps.

- Some scientists are highly creative and make substantial contributions in their fields, but they always build on other people's ideas.

- All scientists must use their imagination when contributing to the development of science.

- Scientific theories are created in many different ways. The processes are sometimes highly creative and/or highly logic, rational and/or accidental.

- In science creativity and rationality always work together. Scientific creativity never works without rationality and strict empirical testing.

This reliable picture is important to consider when approaching scientific creativity in the context of school science and science education. The reason is it can provide the background and rationale for designing activities, which have the potential to foster creativity in school science education. However, two ideas that do not explicitly appear in the above list are 1) The aesthetic dimension of science of scientific knowledge (Girod, 2007) and 2) the idea of scientific inquiry, which includes asking questions, problem solving, designing and conducting investigations, forming hypothesis formation and formulating explanations, and also reflecting upon explanations and findings (Barrow, 2010). Although implicit in the above list, these two ideas, along with imagination, need to be seriously considered by science teachers and science educators in approaching scientific creativity. Iimagination, as a mental ability that has a close relationship with scientific creativity, deserves special attention. As McComas (1998) has pointed out, "close inspection will reveal that scientists approach and solve problems with imagination and creativity, prior knowledge and perseverance.” (p. 58).

Imagination, as an ability that allows one to form mental images and also to think of the possible rather than just the actual (Egan, 1990), and "to play with different hypotheses" and "with different ways of making objects” (Gaut, 2003: p. 280), is not simply important but central to science. For scientists, in their attempt to understand how the world works, visualize unobservable entities (i.e., atoms, electrons, lines of force) and phenomena (i.e., electromagnetic induction, change in intermolecular distance) and also think of possible ways to explain phenomena. They also play with ideas, with different possibilities, through 
thought experiments, analogies and modelling. It must have been in the aforementioned sense that Einstein considered imagination more important than knowledge. For he is reputed to have said that while knowledge points to what there is, imagination points to what there can be. And he also urged people who want to become scientists to take thirty minutes a day and think like non-scientists (Di Trocchio, 1997).

That imagination is the sine qua non of science can been seen not only in its role in some indispensable mental abilities, such as re-imagining problems, creating mental images, and possibility thinking, but also in its central role in narrative thinking. This kind of thinking is completely divergent and complements logicomathematical thinking (Bruner, 1986). There is evidence that narrative thinking is central to science (Hadzigeorgiou \& Stefanich, 2001; Klassen, 2006). As Nobel Prize winner Peter Medawar commented, scientists, in building exploratory structures, are in fact "telling stories which are scrupulously tested to see if they are stories about real life” (Medawar, 1984: p. 133). Explanatory schemes (i.e., hypotheses, theories) are the result of both narrative and logico-mathematical thinking, since the latter checks and tests ideas generated by the former, no matter how imaginative, against reality and also in relation to what is already known about reality. This complementary, but at the same time central, role of the imaginative element in science has been stressed by Richard Feynman as follows:

The test of all knowledge is experiment. Experiment is the sole judge of scientific "truth". But what is the source of knowledge? Where do the laws to be tested come from? Experiment, itself, helps to produce these laws, in the sense that it gives us hints. But also needed is imagination to create from these hints the great generalizations-to guess at the wonderful, simple, but very strange patterns beneath them all, and then to experiment to check again whether we have made the right guess. (Feynman, 1995: p. 2)

Feynman's view concurs with that of Holton (1996), who believes that "logic, experimental skill, and mathematics are constant guides" but "are by no means adequate to the task of scientific investigation” (p. 78). But Holton (1996) goes further, in that he distinguishes between three types of imagination, that is, "three closely related companions that are rarely acknowledged: the visual imagination, the metaphoric imagination, and the thematic imagination" (p. 78).

Yet imagination is one of those concepts whose importance cannot be found in scientific reports and various research papers. It can be found though where scientists speak about their life and about the role of imagination in their work and in other scientists' work. Van't Hoff, for example, in a letter to his father, wrote: "The fact is the basis, the foundation. Imagination the building material, the hypothesis the ground to be tested, and reality is the building" (Van't Hoff, 1967: p. 2). Maxwell, in admiring Faraday's exceptionally imaginative thought said: "Faraday, in his mind's eye, saw lines of force, traversing all space, where the mathematicians saw centres of force attracting at a distance. Faraday saw a medium where mathematicians saw nothing but distance" (McAllister, 1996: p. 54), while Planck (1933: p. 215) did remark that: "Imaginative vision and faith in the ultimate success are indispensable. The pure rationalist has no place here" (meaning "no place" in modern physics).

It is therefore important that the role of imagination in the creation of scientific knowledge be acknowledged. What GellMann, a Nobel laureate in physics, has said is certainly important: "Rationality is one the many factors governing human behaviour, and it is by no means always the dominant factor." (Jenkins, 1996: p. 147). Yet imagination, as the analysis so far suggests, is a mental ability that should be explicitly linked with science, and therefore with science education.

\section{Creativity in Science Education}

The answer to the question "what does creativity in science education mean?” may seem quite straightforward. For one can readily say that creativity in the context of science education refers, or should refer, to what the science teacher does (i.e., s/he stimulates and encourages creative thinking) and/or to the opportunities the students have, independently and/or as a result of what their teacher does, for creative thinking. What is not straightforward, however, is the extent to which creativity in the context of the science classroom can or should reflect scientific creativity. For it sounds reasonable, one might say, that creativity in the context of science education should reflect, as much as possible, the notion of scientific creativity. There is a view that any approach to scientific creativity in the context of school science should be both "authentic" in scientific research terms and meaningful and appropriate to the students' needs and abilities (Kind \& Kind, 2007). However, the idea of "authenticity” may be misleading.

Although "scientific creativity" should reflect what real scientists do, the differences between scientists and children as well as the nature of the tasks encountered by them need to be taken into account. Children have neither the scientists' conceptual framework nor the time to pursue a topic for a long time, unless of course this has been arranged (i.e., through participation in a project, that poses no immediate restrictions on time). Moreover the deliberate pursuit of novelty by scientists may be totally absent from students, who may very well do things, including scientific inquiry, because they have to. The nature of the problems scientists encounter is also another issue (i.e., illstructured problems admitting multiple solutions) to be seriously considered. This point I take up further down this section of the paper.

A point also that needs to be made here is that although we know what real scientists do, we cannot say the same about what and how they think. Given that there is no "universal scientific methodology", scientists can approach and solve the problems they face in their research in many possible ways (see Simonton, 2004). Moreover, as Medawar (1979) observes, "Scientists are people of very dissimilar temperaments doing different things in very different ways" (p. 3). In other words, scientific creativity emerges from experiences extremely unique to the individual scientists. Even if some students had conceptual frameworks similar to those of scientists, the nature of creativity, as an emergent intellectual ability, would make the comparison between students and scientists unrealistic. All these arguments make "authenticity" an unreliable, if not invalid, criterion whereby one judges scientific creativity in the context of school science.

The issue of "authenticity", however, becomes more complex if one considers it the context of scientific inquiry. For there is also a crucial question: "how authentic can inquiry science be?" Are students really free to explore or are somehow guided by their teachers to follow a step-by-step procedure (i.e., collect and analyze), if not a recipe for inquiry (Asay \& Orgill, 2010). The main flaw with inquiry science, as Kind and Kind (2007) have observed, is that the freedom and openness existing in real science is rarely achieved in the everyday reality of the science 
classroom, and, more often than not, teachers inevitably "frame" student inquiry, by facilitating and providing most of what is required in the investigation. There is some evidence, as they report, to argue that scientific inquiry does not offer any guarantee for fostering students' scientific creativity. In fact this evidence suggests that "any claims that "scientific creativity" is developed through inquiry science are certainly spurious" (Kind \& Kind, 2007: p. 27). Moreover, it is questionable whether the fact that different groups of students come up with different ways to answer questions and approach problems (Barrow, 2010) can be taken as an indication or a criterion whereby one can judge scientific creativity.

Yet these words of caution do not imply that inquiry science cannot be creative. Three examples can help illustrate the point here In a science class a teacher provides the groups of students with certain materials, like batteries, wires and light bulbs, and asks them to make the light bulb light. In another classroom students are asked to make a model of a house and investigate how illumination (with light coming from the sun) within the house can increase. And in another classroom students are asked to investigate and then come up with an explanation, how substances like sugar and salt, affect the evaporation rate of the water in a container. Here one can see three different activities with the first requiring little imagination and divergent thinking - trial and error suffices to get the simple system working, the second requiring imagination and divergent thinking in order for students to try possible factors that might affect the illumination in the house (i.e., the position of windows, the colour of curtains, the arrangement of furniture), and the third requiring the creative formation of a theory to explain why adding substances such as salt or sugar to water causes the water to evaporate more slowly at a given temperature. (Students will have to visualize water molecules forming bonds with sugar or salt molecules, so it will take extra energy to break those bonds thus slowing down the evaporation process). Of course, different variables here, like distilled water and tap water, may be included in the investigation, making the whole process even more creative (Barrow, 2010). And despite a lack of conclusive evidence resulting from a critical evaluation of some inquiry science approaches to scientific creativity, programs that offer extended opportunities for project work over a longer period of time, demanding student commitment and ownership, appear to be more promising as far as the development of creativity is concerned. Such programs appear to meet "creativity" criteria to a greater extend than traditional inquiry teaching (Kind \& Kind, 2007).

A word of caution, however, should also be said about art. True, art is an excellent tool to help students learn science (Ashley, 2011; Merten, 2011). For example, students who make a collage, illustrating the water cycle or the states of water, are helped to learn science content. Moreover, for some students, such an activity can be a great stimulus for learning. But this is different from saying that this activity necessarily helps students develop scientific creativity, in the sense that they can successfully approach activities that "explicitly" encourage divergent/imaginative thinking (e.g., creating an analogy for the water cycle or the states of water, writing about the daily life of a photon). For although an art-based science activity requires imaginative/divergent thinking, the differences between "artistic" and "scientific" creativity need to be seriously considered. The point that is being made here is that participation in an art activity may inspire and motivate students but may not make them use their creative imagination in order to approach other tasks and activities, like problem solving and inquiry.

Yet, in talking about two different kinds of creativity, that is, "artistic" and "scientific" creativity, one should also bear in mind that the two are not so distinguishable (see previous section). And the fact that this particular activity (i.e., making a collage), like other art-based activities, can lead to an aesthetic experience, and hence to a creative moment, involving even an imaginative leap and a sudden insight, is a point that needs particular attention (Watts, 2001; Hadzigeorgiou \& Fotinos, 2007). If science is indeed "a holistic enterprise that may be influenced by art, music, dance, yoga, meditation, imagination, wonder and may other things" (Lunn \& Nobel, 2008: p. 803), then art, through the possibilities it can provide for aesthetic experiences, should be considered an excellent avenue to an aesthetic kind understanding, which is documented in the literature regarding both science and science education (Girod, 2007). Jackson's (1998: p. 33) argument provides not only a justification of art and science connections in the curriculum, but also an answer to the question regarding how one can induce an aesthetic/transformative understanding of school science:

The arts do more than provide us with fleeting moments of elation and delight. They expand our horizons. They contribute meaning and value to future experience. They modify our ways of perceiving the world, thus leaving us and the world itself irrevocably changed.

This idea of aesthetic/transformative experience in regard to scientific creativity is crucial, since it relates directly to creativity, namely, to the ability to see things and ideas in novel and unusual ways (Gardner, 1993a, 1993b, 2010; Sternberg, 2006). The development of this ability, or at least the effort to foster it, can be considered an important goal regarding scientific creativity, and should complement two more (traditional) goals, such as 1) The generation of multiple ideas (i.e., solutions to problems, answers to questions), and evaluation of those, which are worthwhile to be pursued further; and 2) Making associations between semantically remote or seemingly unrelated ideas, events, and phenomena (Craft, 2001; Sternberg, 2006). It is apparent that the above three goals concerning creativity in school science are both compatible with the general notion of creativity (Sternberg, 2006; Gardner, 2010) and scientific creativity in particular (Kind \& Kind, 2007; Gardner, 1993b, 1997; Schmidt, 2011; Simonton, 2004), and also realistic in the context of science education, in the sense that activities aiming to achieve them can be designed and implemented (Hadzigeorgiou \& Fotinos, 2007; see next section).

The above goals necessitate a distinction between an innovative teaching approach and an approach that provides opportunities for creative thinking. Helping students to think creatively in the context of school science is certainly very different form both teaching them creatively (i.e., by implementing an innovative approach) and teaching them about the nature of science, in order to help them become aware of and appreciate science as a creative endeavour. It is also helpful, in the sense that a distinction between learning to be novel in the context of everyday life is very different from learning to be creative in science (Rowlands, 2011). It is for these reasons that the distinction between three frames, namely "creative teaching”, "teaching about creativity" and "fostering students scientific creativity" (Kind \& Kind, 2007), is important to consider. Such distinction focuses our attention on what we really do or on what we really want to do.

The above goals also necessitate a special attention to imag- 
ination. There is empirical evidence to support the view the people who have opportunities to operate in imagined worlds become more creative. And although the evidence that imaginative skills in science education are transferable to other areas is not convincing, there is good reason to believe that "imagination offers the promise of making scientific creativity more concrete and helping to identify a potential starting point for further research" (Kind \& Kind, 2007: p. 25). The work done by the Imaginative Education Research Group (IERG), directed by Kieran Egan at Simon Fraser University, is promising, at least as far as the role of imagination in learning is concerned. More research is certainly needed, especially in regard to creativity (Kind \& Kind, 2007), but, nonetheless, such research needs to be based upon a theoretical framework, which gives primacy to imagination.

\section{Fostering Creativity in the Science Classroom}

The discussion thus far begs the question: How can we best foster students' scientific creativity? This discussion may have been illuminating, yet the evidence about the effectiveness of certain teaching strategies (i.e., imagery/visualization, inquiry science, integrating art with science) is inconclusive. An analysis, in fact, of research studies in science education points to the fact that "creativity in school science is at a much lower level than is required even to begin approaching an answer" (Kind \& Kind, 2007: p. 2). Moreover, research based on the life stories of scientists (e.g., Einstein, Maxwell, Faraday, Watts, Feynman) questions the development of students' imaginative skills by formal schooling. For as Shepard (1988) has pointed out, "their development occurs before, outside of or perhaps in spite of such schooling-apparently through active but largely solitary interaction with physical objects of one's world" (p. 181). All these make the development of students' creativity a real challenge. This challenge becomes even greater if we consider the fact that creativity is grounded in knowledge, and therefore science teachers should help students build content knowledge, but "without killing the creativity" (Boden, 2001: p. 102).

However, the above question can still be answered in the affirmative, if we consider what we know about creativity in general, namely, that individuals can become creative through the confluence of several factors, including the environment and the challenges it offers (Robinson, 2001; Sternberg, 2006). Moving beyond the rhetoric, by carefully analysing and reflecting on current practices that supposedly help students develop their creativity can be more fruitful than simply following the trend and adopting and implementing those practices. Even if one believes that creativity is to a large extent a matter of innate ability, talent, and capability (Moravcsik, 1981: p. 227), one can nevertheless acknowledge that "there are many ways in which science education can locate, foster, encourage, practice, and enhance traits, attitudes, and skills in the students so that whatever creativity the student has, it is more effectively converted into achievements and accomplishments.” (p. 227).

Having already made reference to ideas from the nature of science that have a bearing on creativity (i.e., the social nature of science, its aesthetic dimension, the idea of scientific inquiry, and the role of imagery and imagination in science), and considering evidence from research on the effect of temporal and spatial distance on creativity (Shapira \& Liberman, 2009), it goes without saying that a notion of creativity in the context of school science should certainly take these ideas into account and should also be compatible with the general notion of creativity. A few points that are crucial for designing activities can be reiterated here.

First, the fostering of creativity presupposes a strong conceptual framework. In other words, science content knowledge is a prerequisite for thinking and hence a prerequisite for creative thinking. Students should be as knowledgeable about science (i.e., content knowledge) as possible.

Second, creativity in science education is about divergent/ imaginative thinking. Encouraging creativity in the context of school science means encouraging idea generation in a nonthreatening and critique-free environment. This means that, in order for students to be creative, all ideas need to be heard and not ridiculed, no matter how crazy the may sound. Di Trocchio (1997) provides ample evidence that what once thought to be a crazy idea was finally accepted by the scientific community (i.e., the transmission of electromagnetic waves over long distances, the splitting of the atom, the general theory of relativity).

Third, imagery and visualization should have a central place in science curriculum and teaching. As Mathewson (1999) pointed out, visual-spatial thinking is an overlooked aspect of science education.

Fourth, the ideas of "aesthetic experience" and particularly the notion of wonder need special attention. An aesthetic experience, particularly when accompanied by a sense of wonder, increases the possibilities for deeper engagement in science and inspiration (Hadzigeorgiou, 2005).

Fifth, thinking about future events and possibilities (i.e., temporal distance) and also about far away events and people (i.e., spatial distance) is a strategy that can be incorporated in teaching activities.

Sixth, (although an argument about whether individual creativity is superior or inferior to social creativity is hard to defend, or maybe meaningless in the sense that there is an interplay between the two) the social nature of science, as has already been discussed, points to activities that provide students with opportunities to interact in a social setting, thinking imaginatively and divergently. In short, creativity, without completely excluding individualized activities, should be fostered within a socio-cultural milieu. This milieu includes both the culture of scientific inquiry and the culture of the school classroom, and both cultures can play a role in developing students' creative thinking.

However, a few words about evaluating the results of our teaching should also be said here. Given that no one can predict the emergence of creativity - given the nature of creativity, and scientific creativity in particular as was discussed, there appears to be a problem. This is not to say that creative thinking cannot be recognized. On the contrary, we can tell when we see it. The problem is that, even if one teaches deliberately for creative thinking, one cannot expect to assess it when one wants to assess it, as a result or consequence of his/her teaching. The problem becomes more complicated if one considers the fact that, regardless of the opportunities students have for creative thinking, the testing situation may not provide a reliable means to assess creativity. For the test itself may be felt as a constraint on a student's freedom. And the inauthentic situation in which it is taken may also be a constraint on his/her ability to thin creatively. According to the literature, freedom and authentic situations can be considered, among other factors, preconditions for creativity, since they both relate to motivation, purpose, exploration, and confidence (Gardner, 1993b; Mumford, 2003; 
Sternberg, 2006; see also Simonton, 2004).

So the best we, as science educators and science teachers, can do is to provide an environment that increases the possibilities for creativity to emerge. In the light of what has been discussed so far, some activities can be considered more appropriate for fostering scientific creativity in science education. Those are activities that are more likely 1 ) To provide opportunities for imaginative/divergent thinking; and 2) To lead to aesthetic experiences. These activities are compatible with the three goals regarding creative thinking in science education (see previous section). For the achievement of the first two goals require divergent/imaginative thinking, while the third one, in addition to such kind of thinking, presupposes a sense of wonder and aesthetic experiences in general.

Compatible with these goals and what has been thus far about scientific creativity, the following activities, although not a recipe, have the potential to increase the possibilities for students' creativity to emerge:

- Creative problem solving (e.g., measuring the height of a building using a barometer or tennis ball, measuring the surface of an irregular shape using a mechanical balance, the fate of the earth after the total disappearance of the sun, calculating the density of a proton, of a black hole).

- Problem solving in the STS context (e.g., how technology might affect the environment in the future, how we can produce electrical power in the future, how we might approach the sudden invasion of bacteria from space).

- Creative writing (e.g., a day in the life of a proton, a day without gravity).

- Creative science inquiry (e.g., investigating possible factors that might have an effect on the illumination of a room, the construction of a flashlight from simple materials, ways to produce electricity for the house in a case of emergency, ways to heat water in the absence of metal containers).

- Creating analogies to understand phenomena and ideas (e.g., the phenomenon of resonance, the ideas energy, nuclear fission and fusion, chemical bonding).

- Challenging students to find connections among apparently unrelated facts and ideas (e.g., what would be a connection between Newton's laws, a nurse and a soccer-player? Between light, electrons and a surgeon? Between a glass of wine, the age of the universe and the evolution of stars? Between the sinking of Titanic and hydrogen bonding).

- Mystery solving (e.g., detective work in order to explain the disappearance of something, like a certain volume of liquid, to find something that is missing, like a beam of light, to find connection between seemingly unrelated ideas, as in the case between a thief, the police and the speed of light).

- Approaching the teaching and learning of science through the arts (e.g., using photography and making a collage to present the results of a study of a topic such as the effect of modern technology on everyday life, using technologies to construct scientific models, using drawing to represent a phenomenon, such as photosynthesis).

\section{Concluding Comments}

Whether or not one agrees with the idea that the development of creativity should be the first most important goal of education, is irrelevant when it comes to the notion of scientific creativity. Given that imagination and creativity are considered central to the nature of science, a good science education cannot help but foster students' imaginative skills and creativity. If all learning is a possibility (Brent, Sumara, \& Luce-Kapler, 2008; Hadzigeorgiou, 2005), the development of students' creative powers through science learning is a possibility too. Maslow's (1968) distinction between "special talent creativeness" and "selfactualizing creativeness" can provide food for thought for those who are willing to make school science, not just an adventure, but a creative endeavour too, so that students' creative acts will be both acts of self-expression and acts of self-actualization. Although "special talent" creativity" has played a catalytic role in the development of our civilization, in the context of education, "self-actualizing" creativity appears to be a much more realistic notion and also a more fruitful and promising one. Carl Rogers' (1961) definition of creativity as "the emergence in action of a novel relational product growing out of the uniqueness of the individual on the one hand, and the materials, events, people or circumstances of his life on the other," (p. 351), when applied to education, makes the distinction between the various degrees and/or kinds of creativity (as found in the literature) unimportant and orients us to the process of wholehearted engagement, as the first necessary condition of creativity (Csikszentmihalyi, 1996). Perhaps, if approached from this perspective, creativity in school science can open new vistas for both teachers and students, and can provide an answer to the perennial problem of students' engagement in science.

\section{REFERENCES}

Asay, L. \& Orgill, M. (2010). Analysis of essential features of inquiry in articles published in The Science Teacher. Journal of Science Teacher Education, 21, 57-79. doi:10.1007/s10972-009-9152-9

Ashley, C. (2011). Avenues to Inspiration. Science Scope, 35, 24-30.

Barrow, L. (2010). Encouraging creativity with scientific inquiry. Creative Education, 1, 1-16. doi:10.4236/ce.2010.11001

Boden, M. (2001). Creativity and knowledge. In A. Craft, B. Jeffrey, \& M. Leibling (Eds.), Creativity in education (pp. 95-102). London: Continuum.

Boden, M. (2004). The creative mind: Myths and mechanisms. New York: Routledge.

Bohm, D. (1998). On creativity. London: Routledge.

Brent, D., Sumara, D., \& Luce-Kapler, R. (2008). Engaging minds: Changing teaching in complex times. New York: Routledge.

Bruner, J. (1986). Actual minds, possible worlds. Cambridge, MA: Harvard University Press.

Craft, A. (2001). Little C creativity. In A. Craft, B. Jeffrey, \& M. Leibling (Eds.), Creativity in education. New York: Continuum International.

Csikszentmihalyi, M. (1994). The domain of creativity. In D. Feldman, M. Csikszentmihalyi, \& H. Gardner (Eds.), Changing the world: A framework of the study of creativity (pp. 135-158). Westport, CT: Praeger.

Csikszentmihalyi, M. (1996). Creativity: Flow and the psychology of discovery and invention. New York: Harper Collins.

Dietrich, A. (2004). The cognitive neuroscience of creativity. Psychonomic Bulletin \& Review, 11, 1011-1026. doi:10.3758/BF03196731

Drayton, B., \& Falk, J. (2001). Tell-tale signs of the inquiry oriented classroom. NASSP Bulletin, 85, 24-34. doi:10.1177/019263650108562304

Di Trocchio, F. (1997). Il genio incompress. Milan: Mondadori.

Egan, K. (1990). Romantic understanding. Chicago: University of Chicago Press.

Einstein, A., \& Infeld, L. (1938). The evolution of physics. Cambridge: Cambridge University Press.

Feynman, R. (1995). Six easy pieces. Reading, MA: Helix Books. Feldman, D., Czikszentmihalyi, M., \& Gardner, H. (1994). Changing 
the world: A framework for the study of creativity. Westport, CT and London: Praeger.

Gardner, H. (1993a). Multiple intelligences. The theory in practice. New York: Basic Books.

Gardner, H. (1993b). Creating minds. New York: Basic Books.

Gardner, H. (2004). Changing minds: The art and science of changing our own and other people's minds. Boston: Harvard Business School Press.

Gardner, H. (1997). Extraordinary minds. New York: Harper Collins.

Gardner, H. (2010). Five minds for the future. Cambridge, MA: Harvard Business School Press.

Gaut, B. (2003). Creativity and imagination. In B. Gaut, \& P. Livingston (Eds.), The creation of art (pp. 268-293), Cambridge: Cambridge University Press.

Ginsberg, H., \& Opper, S. (1969). Piaget's theory of intellectual development: An introduction. Englewood Cliffs, NJ: Prentice-Hall, Inc.

Girod, M. (2007). A conceptual overview of the beauty and aesthetics in science. Studies in Science Education, 43, 38-61.

doi:10.1080/03057260708560226

Hadzigeorgiou, Y. (2005). Romantic understanding and science education. Teaching Education, 16, 23-32. doi:10.1080/1047621052000341590

Hadzigeorgiou, Y., \& Stefanich, G. (2001). Imagination in science education. Contemporary Education, 71, 23-29.

Hadzigeorgiou, Y., \& Fotinos, N. (2007). Imaginative thinking and the learning of science. Science Education Review, 6, 15-22.

Heisenberg, W. (1971). Physics and beyond. London: Allen \& Unwin.

Holton, G. (1996). Einstein, history, and other passions. Reading, MA: Addison-Wesley.

Jackson, P. (1998). John Dewey and the lessons of art. New Haven, CT: Yale University Press.

Jenkins, E. (1996). The "nature of science" as a curriculum component. Journal of Curriculum Studies, 28, 137-150. doi:10.1080/0022027980280202

Kind, P., \& Kind, V. (2007). Creativity in science education: Perspectives and challenges for developing school science. Studies in Science Education, 43, 1-37. doi:10.1080/03057260708560225

Klassen, S. (2006). The application of historical narrative in science learning: The Atlantic Cable story. Science \& Education, 16, 335352.

Kuhn, T. (1970). The structure of scientific revolutions. Chicago: University of Chicago Press.

Latour, B., \& Woolgar, S. (1986). Laboratory life: The construction of scientific facts. Princeton, NJ: Princeton University Press.

Lunn, M., \& Nobel, A. (2008). Revisioning science "love and passion in the scientific imagination": Art and science. International Journal of Science Education, 30, 793-805.

doi:10.1080/09500690701264750

Mannheim, K. (1972). Ideology and utopia. London: Routledge and Kegan Paul.

Maslow, A. (1968). Toward a psychology of being. New York: Van Nostrand Reinhold.

Mathewson, J. (1999). Visual-spatial thinking: An aspect of science overlooked by educators. Science Education, 83, 33-54. doi:10.1002/(SICI)1098-237X(199901)83:1<33::AID-SCE2>3.0.CO; 2-Z

McAllister, J. (1996). Beauty and revolution in science. Ithaca, NY: Cornell University Press.

McAllister, J. W. (1997). Laws of nature, natural history, and the description of the world. Princeton: Voordracht Institute for Advanced Study (Conference lecture).

McComas, W. (1998). The principal elements of the nature of science: Dispelling the myths. In W. McComas (Ed.), The nature of science in science education: Rationales and strategies (pp. 53-72). Dordrecht: Kluwer Academic Publishers.

Medawar, P. (1967). The art of the soluble: Originality in science. Middlesex: Penguin Books.

Medawar, P. (1979). Advice to a young scientist. New York: Harper \&
Row.

Medawar, P. (1984). Pluto's republic. Oxford: Oxford University Press.

Merten, S. (2011). Enhancing science education through art. Science Scope, 35, 31-35.

Miell, D., \& Littleton, K. (2004). Collaborative creativity: Contemporary perspectives. London: Free Association Books.

Miller, A. (2001). Einstein, Picasso: Space, Time, and the Beauty That Causes Havoc. New York: Basic Books.

Moravcsik, M. J. (1981). Creativity in science education. Science Education, 65, 221-227. doi:10.1002/sce.3730650212

Mumford, M. D. (2003). Where have we been, where are we going? Taking stock in creativity research. Creativity Research Journal, 15, 107-120. doi:10.1080/10400419.2003.9651403

Osborne, J., Collins, S., Ratcliffe, M., Millar, R., \& Duschl, R. (2003). What "ideas-about-science" should be taught in school? A Delphi study of the expert community. Journal of Research in Science Teaching, 40, 692-720. doi:10.1002/tea.10105

Pink, D. (2005). A whole new mind. New York: Riverhead Trade.

Planck, M. (1933). Where is science going? London: Allen \& Unwin.

Ricchiuto, J. (1996). Collaborative creativity. Cleveland, OH: Oakhill Press.

Robinson, K. (2001). Out of our minds. Learning to be creative. Chichester: Capstone.

Rogers, C. (1961). On becoming a person. Boston, MA: Houghton, Mifflin.

Root-Bernstein, R. (1996). The sciences and arts share a common creative aesthetic. In A. Tauber (Ed.), The elusive synthesis. Aesthetics and science (pp. 49-82). Boston, London: Kluwer.

doi:10.1007/978-94-009-1786-6_3

Root-Bernstein, R. (2002). Aesthetic cognition. International Studies in Philosophy of Science, 16, 61-77. doi:10.1080/02698590120118837

Rowlands, S. (2011). Discussion article: Disciplinary boundaries for creativity. Creative Education, 2, 47-55.

doi:10.4236/ce.2011.21007

Schmidt, A. (2011). Creativity in science: Tensions between perceptions and practice. Creative Education, 2, 435-445. doi:10.4236/ce.2011.25063

Schwartz, R. S., Lederman, N. G., \& Crawford, B. A. (2004). Developing views of nature of science in an authentic context: An explicit approach to bridging the gap between nature of science and scientific inquiry. Science Education, 88, 610-645. doi:10.1002/sce.10128

Shapira, O., \& Liberman, N. (2009). Why thinking about distant things can make us more creative. URL (last checked 3 February 2012). http://www.scientificamerican.com/article.cfm?id=an-easy-way-to-in crease-c\#comments

Shepard, R. (1988). The imagination of the scientists. In K. Egan, \& D. Nadaner (Eds.), Imagination and education (pp. 153-185). New York: Teachers College Press.

Simonton, D. (2004). Creativity in science: Chance, logic, genius, and zeitgeist. Cambridge: Cambridge University Press. doi:10.1017/CBO9781139165358

Sternberg, R. J. (2006). Creating a vision of creativity: The first 25 years. Psychology of Aesthetics, Creativity, and the Arts, 1, 2-12. doi:10.1037/1931-3896.S.1.2

Tauber, A. (1996). The elusive synthesis. Science and aesthetics. Boston, London: Kluwer. doi:10.1007/978-94-009-1786-6

Tolstory, I. (1990). The knowledge and the power: Reflection on the history of science. London: Canongate.

Trefil, J. (2003). The nature of science: An A-Z guide to the laws and principles governing the universe. Boston, MA: Houghton-Mifflin.

Van't Hoff, J. (1967). Imagination in science. New York: SprigerVerlag. doi:10.1007/978-3-642-87040-8

Vernon, P. (1970). Creativity: Selected readings. Harmondsworth: Penguin.

Watts, M. (2001). Science and poetry: Passion vs prescription in school science? International Journal of Science Education, 23, 197-208. doi:10.1080/09500690120685 


\section{Y. HADZIGEORGIOU ET AL.}

Whitehead, A. (1957). The aims of education. New York: Free Press. Woolgar, S. (1988). Science: The very idea. London: Routledge.

Zenasni, F., Besancon, M., \& Lubart, T. (2011). Creativity and to- lerance of ambiguity: An empirical study. Journal of Creative Behavior, 42, 61-73. doi:10.1002/j.2162-6057.2008.tb01080.x 